\title{
Ethnopharmacobotanical Findings of Medicinal Plants in the Kızılcahamam District of Ankara, Turkey
}

\section{Ankara'nın Kızılcahamam İlçesi (Türkiye) Tıbbi Bitkilerinin Etnofarmakobotanik Bulguları}

\author{
(D) İlhan GÜRBÜZ1*, (D) Gizem ÖZATKAN2, (D) Galip AKAYDIN³, (D) Tuğba GÜNBATAN1 \\ ${ }^{1}$ Gazi University Faculty of Pharmacy, Department of Pharmacognosy, Ankara, Turkey \\ 2Turkish Medicines and Medical Devices Agency, Department of Medicines Marketing Authorization, Ankara, Turkey \\ 3 Hacettepe University Faculty of Vocational Education, Department of Biology, Ankara, Turkey
}

\begin{abstract}
Objectives: Folk medicines in Kızılcıhamam has not been investigated in detail so far. Thus, this study aimed to conduct a comprehensive investigation of folk medicine in the Kızılcahamam district.

Materials and Methods: Nine scientific field trips were organized to Kızılcahamam between April 2007 and July 2008. Data were obtained by field interviews with local people using open and semi-structured questionnaires. Results were evaluated statistically with the "use-value", "informant consensus factor" and cultural importance index.

Results: Sixty-five species (69 taxa) that belong to 58 genera of 31 families were determined to be used as folk medicines. To the best of our knowledge, this is the first study to record four of these species as folk medicines. Plants from Compositae, Lamiaceae and Rosaceae families were used most frequently as folk medicines in Kızılcahamam. Plants in the study area are mainly used for gastrointestinal system problems, respiratory disorders, and urinary tract diseases. Residents from $41 \%$ of the villages where the scientific trips were carried out, declared that they are not using or interested in folk medicines.
\end{abstract}

Conclusion: This study highlights once again the gradual reduction of folk medicinal knowledge and the urgent need for folk medicine investigations in all parts of Turkey.

Key words: Ankara, folk medicines, ethnobotany, medicinal plants, Kızılcahamam

öz

Amaç: Kızılcahamam halk ilaçları şu ana kadar detaylı bir şekilde araştırılmamıştır. Bu nedenle, bu çalışmada Kızılcahamam ilçesinin halk ilaçlarının kapsamlı bir şekilde incelenmesi amaçlanmıştır.

Gereç ve Yöntemler: 2007 yılı Nisan ayı ile 2008 yılı Temmuz ayları arasında Kızılcahamam'a dokuz bilimsel saha gezisi düzenlenmiștir. Veriler saha çalışmaları esnasında yerel halk ile yapılan açık ve yarı yapılandırılmış bir anket kullanılarak elde edilmiştir. Sonuçlar istatistiksel olarak "kullanım değeri", "bilgilendirici fikir birliği faktörü" ve "kültürel önem endeksi” hesaplanarak değerlendirilmiștir.

Bulgular: Otuz bir familyadan 58 cinse ait 65 türün (69 takson) halk ilacı olarak kullanıldığı belirlenmiștir. Bildiğimiz kadarıyla bu türlerden dördü ilk kez bu çalışma ile halk ilacı olarak kayıt altına alınmıştır. Kızılcahamam'da en çok Compositae, Lamiaceae ve Rosaceae familyalarından bitkilerin halk ilacı olarak kullanıldığı belirlenmiștir. Çalıșma alanındaki bitkiler, ağırlıklı olarak mide-bağırsak sistemi problemleri, solunum ve idrar yolu hastalıkları için kullanılmaktadır. Bilimsel gezilerin yapıldığı köylerin \%41'inde görüşülen kişiler halk ilaçları kullanmadıklarını veya halk ilaçları ile ilgilenmediklerini beyan etmișlerdir.

Sonuç: Türkiye'nin her bölgesinde halk ilacı bilgisinin giderek azaldığı ve halk ilacı araştırmalarına acil ihtiyaç duyulduğu bu çalışma ile bir kez daha vurgulanmıştır.

Anahtar kelimeler: Ankara, halk ilaçları, etnobotani, tıbbi bitkiler, Kızılcahamam

*Correspondence: igurbuz@gazi.edu.tr or ilgurbuz@gmail.com ,Phone: +90 31220231 79, ORCID-ID: orcid.org/0000-0002-3670-0899

Received: 05.02.2021, Accepted: 04.03.2021

๑Turk J Pharm Sci, Published by Galenos Publishing House. 


\section{INTRODUCTION}

Turkey has a quite rich flora with approximately 12,000 taxa.' Considering factors such as geographic position, topographical structure, climate, and richness of flora, forming a bridge between the east and west and hosting many civilizations and ethnic diversity, the Anatolian Peninsula is an extremely important region for folk medicines. This important knowledge, gained through trial and error for centuries and transferred from generation to generation, is also an important resource for herbal drug research. Nevertheless, this valuable knowledge is rapidly disappearing because of factors such as migration from villages to big cities, easy access to physicians and pharmacies, young people's indifference to folk medicines, and industrialization and destruction of nature. ${ }^{2-4}$ For the aforementioned reasons, this rapidly disappearing treasure of Turkey should be investigated and recorded by experts comprehensively.

One of the cities that need to be studied in terms of ethnobotany in Turkey is Ankara. Despite previous investigations of the ethnobotany of some districts of Ankara, no comprehensive study was conducted in other districts. These studies, conducted in various districts of Ankara, revealed a rich ethnobotanical accumulation. For example, Şimșek et al..$^{5}$ reported that 192 usages for 85 plant species from 31 families were recorded in 25 localities of Beypazarı, Ayaş, and Güdül districts. Sarper et al. ${ }^{6}$ found that 50 plant species from 18 families were used for treatment, food, and similar purposes in the Haymana district. Moreover, Elçi and Erik ${ }^{7}$ revealed that 23 plant species in only six localities in Güdül and Kızılcahamam districts were used for ethnobotanical purposes. Sezik et al. ${ }^{8}$ carried out folk medicine research in 28 localities with sampling method from six districts of Ankara (i.e., Yenimahalle, Kazan, Bala, Altındağ, Keçioren, and Çubuk) and stated that 47 species of 42 genera and 22 families were used as folk medicines. In the Çamlıdere district, the neighbor of Kızılcahamam, 79 plant taxa belonging to 66 genera and 33 families were used for the treatment of various disorders. Additionally, eight new folk medicines were included in the Turkish ethnobotanical inventory in this study. ${ }^{2}$ However, no comprehensive folk medicine study was conducted in the Kızılcahamam district.

The Kizılcahamam district is located in the northern part of Ankara and mainly under the influence of Iran-Turan floristic area because of its location in Central Anatolia. According to taxonomic studies, the flora of Kızılcahamam is quite rich, and three floristic regions are influential in Kızılcahamam, namely, Euro-Siberian, Mediterranean, and Irano-Turanian [Eyüboğlu Ö. Kızılcahamam Soğuksu Milli Parkı'nın Florası (MSc Thesis), Ankara: Gazi University; 1991. Yıldırım A. Kocaçay Vadisi Kızılcahamam-Çeltikçi (Ankara) Arası Segetal Florası (MSc Thesis), Ankara: Gazi University; 1994]. Conversely, the district has a rich cultural heritage, as it is a transit point in Anatolia. ${ }^{9}$ Kizılcahamam is a remarkable study area because of its geographical location, rich biota, cultural accumulation, and significant ethnobotanical findings of neighboring districts [Eyüboğlu Ö. Kızılcahamam Soğuksu Milli Parkı'nın Florası (MSc Thesis), Ankara: Gazi University; 1991. Yıldırım A.
Kocaçay Vadisi Kızılcahamam-Çeltikçi (Ankara) Arası Segetal Florası (MSc Thesis), Ankara: Gazi University; 1994. http:// www.kizilcahamam.gov.tr/]. ${ }^{9}$ To the best of our knowledge, no folk medicine studies have covered the entire Kızılcahamam district. Thus, this study aimed to perform a comprehensive investigation of the folk medicine in the Kızılcahamam district.

\section{MATERIALS AND METHODS}

\section{Research area}

Kızılcahamam is one of the 24 districts of Ankara (Turkey). In history, Kizılcahamam was thought to be used as a settlement place since the Hittites and had been dominated by Phrygians, Scythians, Persians, Alexander the Great, Celts, and Roman Empire. Following the occupation by Arabs in 654, it was again dominated by Roman Empire. By the Malazgirt victory (1071), the majority of the region's population began to be formed by Turks. In the Ottoman Empire period, the Kızılcahamam region was called "Yabanabad," and the region was an important accommodation place that connects Asia and Europe. The first known center of the district is Demirciören village. However, in 1915, the district center moved to Şorba village and remains the center (http://www.kizilcahamam.gov.tr/).

The Kızılcahamam district, which has 105 villages, is situated in north $40.46^{\circ}$ latitude, east $32.65^{\circ}$ longitude (northwest of Ankara), and A4 square according to Davis's grid system (Figure 1).10 It is surrounded by Çubuk in the East, Çamlıdere and Güdül in the West, Ayaş and Kazan in the South, and Çerkeş and Gerede in the north (Figure 1). Its distance to Ankara is $79 \mathrm{~km}$, with acreage of $1712 \mathrm{~km}^{2}$, and altitude of $975 \mathrm{~m}$. Harami Hill (2053 m) and Ișık Mountain $(2030 \mathrm{~m})$, which are the highest places in Ankara, are within the boundaries of the district. Given its broken and mountainous physical structure, the district has plateaus, such as Yemișen, Hıdırlar, Miyala, Salın, Eldelek, Başköy, Yıldııım, and Kırık, and several streams among these plateaus (http://www.kizilcahamam.bel.tr/2103/ Cografi-Konum). Aluç, Beykaya, Yıldırım, and Kavaklı Mountains are the important mountains of the district. Kızılcahamam is quite rich in water resources, in addition to three damns (namely, Kurtboğazı, Eğrekkaya, and Akyar) that satisfy the water requirement of Ankara, and it attracts attention with an abundance of underground water resources. Kocaçay, Kirmir, and Kurtboğazı are important streams of Kızılcahamam.

The region is under the influence of continental and Black Sea climate. It is cold and snowy in winters and hot and droughty in summers. As it has many forests, it is rainy in every season. The average temperature is $+11^{\circ} \mathrm{C}$, and the average humidity is $66 \%$. The highest temperature is observed in August as $+34^{\circ} \mathrm{C}$, while the lowest temperature is observed in February at $-20^{\circ} \mathrm{C}$ (http://www.kizilcahamam.gov.tr/). It has a population of 32,647 , and the main sources of livelihood are agriculture, livestock, apiculture, and spa tourism (http://www.tuik.gov.tr/ Start.do). ${ }^{9}$

The Soğuksu National Park, one of the most important national parks of Turkey, is located within the borders of Kizılcahamam. As it constitutes a transition between steppe and forest 
zones, the Soğuksu National Park, covering 1195 hectares, has an extremely rich biota [Turan M. Fayda-Maliyet Analizi Kapsaminda Kızılcahamam Soğuksu Milli Parkı İncelemesi (MSc), Ankara: Ankara University; 2007). In a study investigating the flora of the Soğuksu National Park, a total of 474 species from 74 families were identified, and 49 of these species were endemic. Researchers also reported that the Soğuksu National Park has the floristic elements of the EuroSiberian and Mediterranean geographical regions. Compositae, Leguminosae, Poaceae, Lamiaceae, and Brassicaceae were the most common families. Forest vegetation mainly consists of Pinus sylvestris L., Pinus nigra J. F. Arnold, Abies nordmanniana (Steven) Spach subsp. equi-trojani (Asch. \& Sint. ex Boiss.) Coode \& Cullen, and Quercus pubescens Willd. [Eyüboğlu Ö. Kızılcahamam Soğuksu Milli Parkı'nın Florası (MSc Thesis), Ankara: Gazi University; 1991].

\section{Field trips}

Nine scientific field trips were organized to Kızılcahamam between April 2007 and July 2008. Generally, brief information about the aim and scope of the study was given to the local authority (called mukhtar) at each settlement area. Afterward, people that are knowledgeable about the folk remedies and elders of villages were reached through mukhtars. Face-toface interviews were conducted in a suitable setting with 57 people by using open and semi-structured questionnaires. Data obtained during the interviews were recorded. General questions (local name of medicinal plants, used parts, purpose of usage, preparation and application method, source of information, etc.) were asked. After each interview, the plants that used as folk medicines were found for in the field under the guidance of the informants. Subsequently, plant samples were taken and appropriately prepared as herbarium materials. To increase the accuracy in identification, flowering or fruiting plants were collected. Therefore, scientific trips were organized to the region between April and July to coincide with the flowering or fruiting period. Plant specimens were identified by Prof. Dr. Galip Akaydın, through Davis's “Flora of Turkey and the East Aegean Islands,"1,10,11 and the Latin names of identified plant species were updated according to The Plant List (http:// www.theplantlist.org/, revision date: 23.02.2021), while the endemism status were checked from "Türkiye Bitkileri Listesi"12 After botanical identification, plant specimens were preserved in Gazi University Faculty of Pharmacy Herbarium (GUEF). Visited locations are shown in Figure 1.
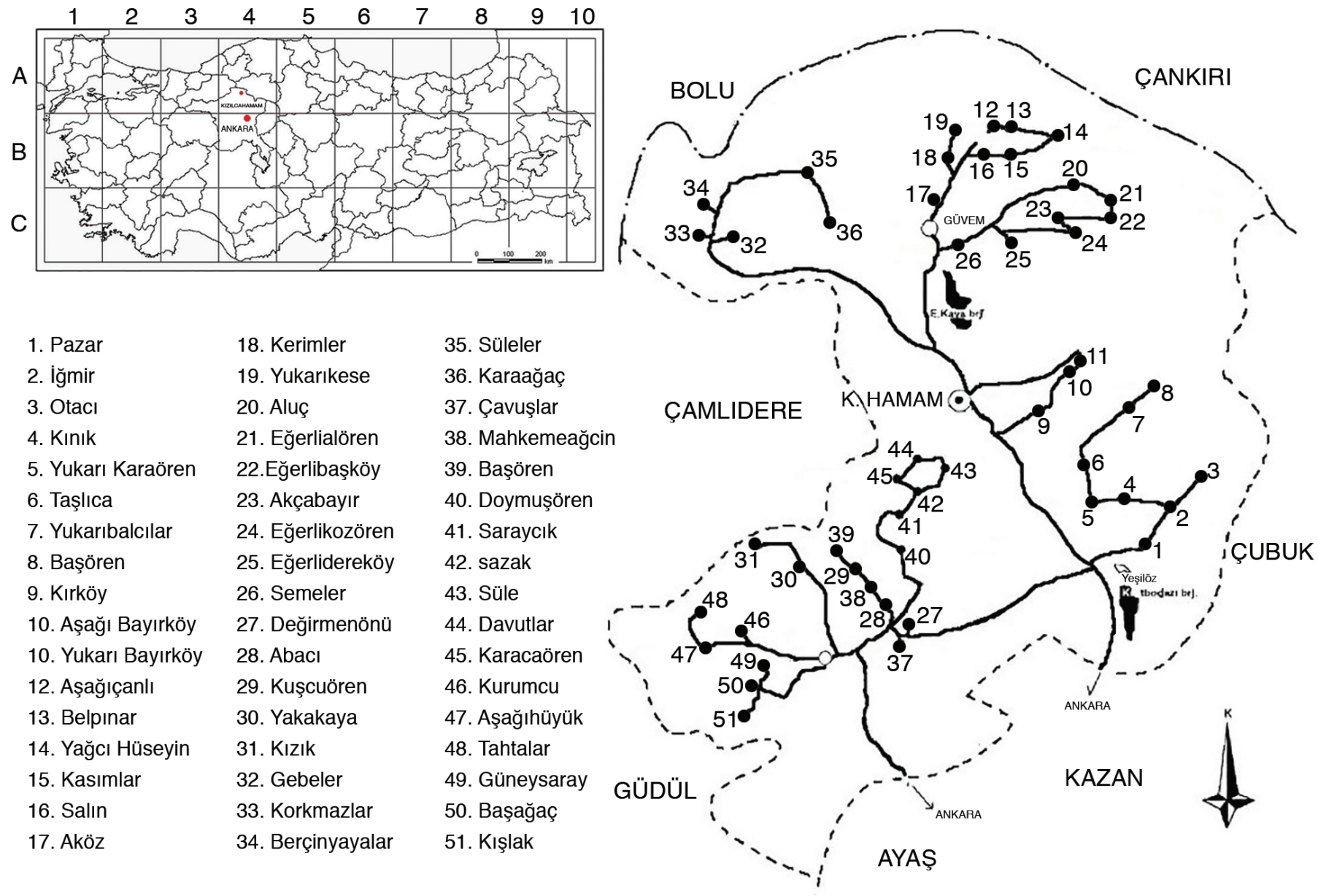

Figure 1. Position of Ankara and Kızılcahamam in Davis's grid system and visited locations 


\section{Statistical analysis}

Initially, the distribution of folk medicines among 11 pharmacological categories was determined. Subsequently, the informant consensus factor (FIC), use value (UV), and cultural importance index $(\mathrm{Cl})$ were calculated using previously described formulas. ${ }^{2}$ High FIC degrees (close to 1) correlate with the consent for the use of folk medicine in specific situations by the informant, while the high UV and $\mathrm{Cl}$ signifies the importance of a plant and high frequency of declaration. ${ }^{13-16}$

\section{RESULTS}

KIzılcahamam folk remedies have not been investigated in detail previously. Thus, the ones that are still not forgotten in the folk medicine accumulation of the district were determined and recorded by field studies. During our research, nine field trips were organized to the district, and 51 localities were visited (Figure 1). After the study, people knowledgeable about folk medicine could be reached in 30 of these locations, while there were no knowledgeable people in the other 21 locations. After the identification of plant specimens, 65 species (69 taxa) from 58 genera and 31 families were determined to be used as folk medicines. While seven of the species used as folk medicines in the district were cultivated plants, the rest were wild. The plants used as folk medicine in Kızılcahamam are compiled together and presented in Table 1. In this table, the Latin names of the medicinal plants are given alphabetically (by family and species name) with other relevant data (GUEF numbers, local names, purpose of usages, preparation, and administration methods).

Table 1 shows that Compositae (13 genera, 12 species, and 13 taxa), Lamiaceae (6 genera, 9 species, and 10 taxa), and Rosaceae ( 7 genera, 9 species, and 9 taxa) are the most commonly referred families in Kızılcahamam as folk medicines (Figure 2). In addition, the most cited plant species are Malva neglecta, Urtica dioica, Pinus nigra subsp. pallasiana, Pinus sylvestris, and Rosa canina (with UV values of $0.29,0.28,0.21$, 0.17 , and 0.17 , respectively). Some differences were noted in this order according to the $\mathrm{Cl}$, Urtica dioica at the first place $(\mathrm{Cl}$ : 0.98), Malva neglecta and Rosa canina at the second place $(\mathrm{Cl}$ :
0.43), and Cota tinctoria and Viscum album at the third rank $(\mathrm{Cl}$ : 0.35) (Table 1).

Folk medicines are generally used after certain preparation methods in the area, while only $32 \%$ of them are used directly. For example, half of the folk medicines used internally are prepared as tea $(33.9 \%$ decoction and $16.7 \%$ infusion) in Kızılcahamam. Some of the internally used folk remedies were prepared as meals (e.g., Beta lomatogona and Malva neglecta), jam (e.g., Rosa canina), or poultice (e.g., Malva neglecta and Quercus robur) before use. Interesting uses such as intrauterine administration of Malva neglecta for women's infertility were also noted (Table 1). Regarding forms of administration, folk medicines were generally used orally (83.4\%) (Table 2).

Folk remedies identified in Kızılcahamam are generally monocomponent and process in a simple preparation. The most preferred plant parts in Kızılcahamam folk medicine are aerial parts, leaf, and fruit. However, inflorescence (e.g., Tilia rubra subsp. caucasica), fresh shoot (e.g., Pinus nigra subsp. pallasiana), phloem (the tissue that appears after peeling the peridem tissue of Pinus sylvestris stem), and whole plant (e.g., Viscum album) are the least used parts (Figure 3 ).

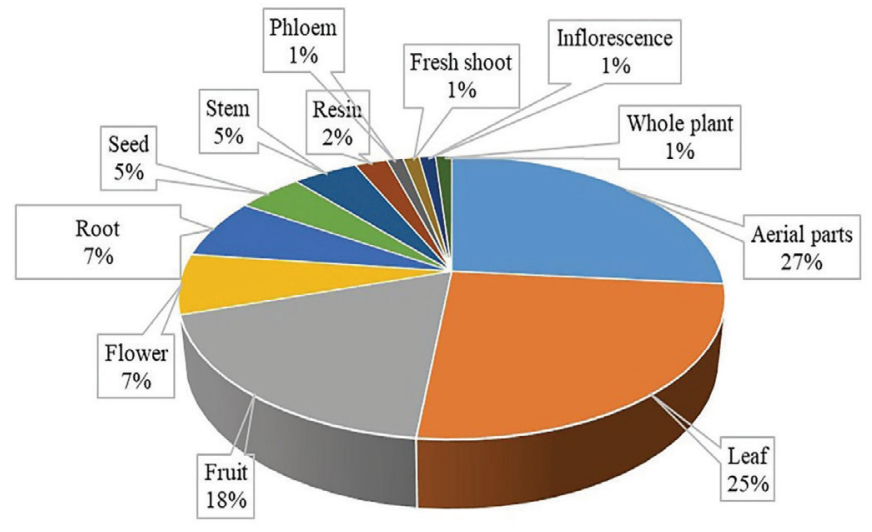

Figure 3. Distribution chart of plants according to used parts

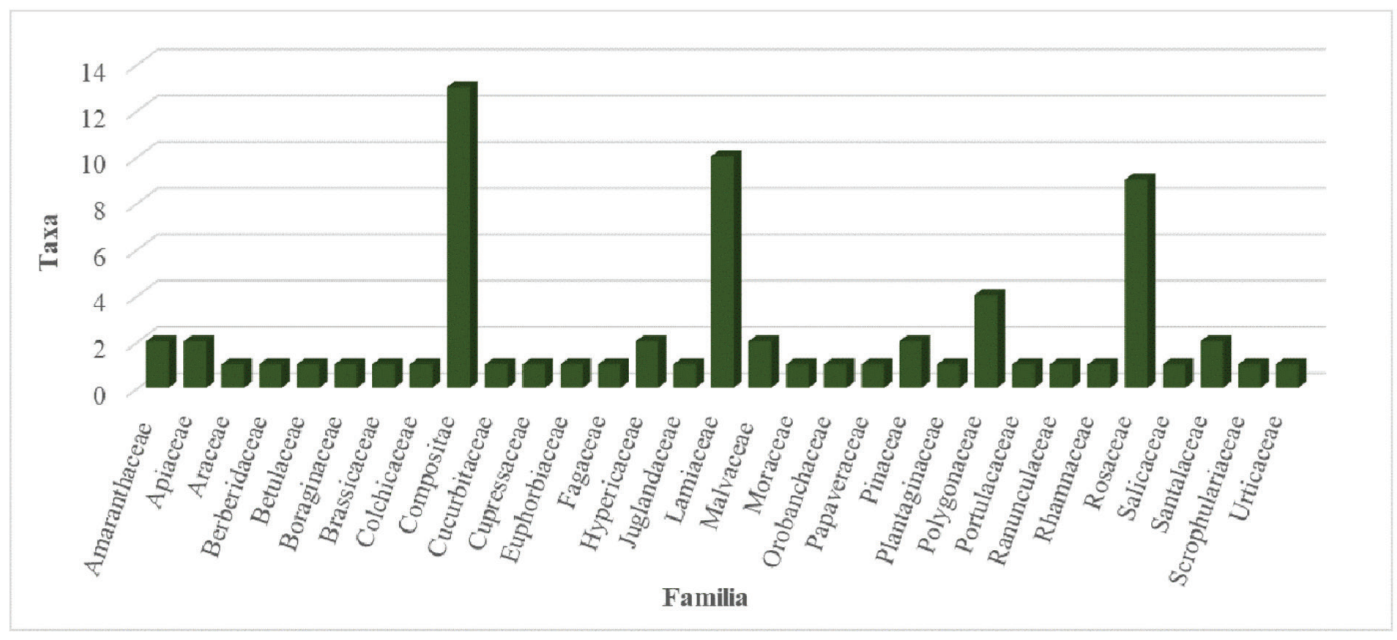

Figure 2. Distribution chart of plants according to family 
Table 1. Ethnobotanical usages of plants in Kızılcahamam district

Family and scientific name (GUEF no)

Locality $^{\mathrm{a}} \quad$ Local name Used part ${ }^{\mathrm{b}}$

Purpose of usage, preparation and application method $^{b}$

UV $\quad \mathrm{Cl}$

Amaranthaceae

Beta lomatogona Fisch. \& C. A. Mey. (2690)

27 Göverek A.p.

For constipation; (I), e.d. or cooked as meal. $\quad 0.03 \quad 0.01$

Chenopodium album L. (2693)

$27 \quad$ Sirken A.p.

A.p.

For constipation; (I), eaten fresh.

$0.01 \quad 0.01$

Apiaceae

Foeniculum vulgare Mill. (2752)*

51

Rezene L.

L.

For stomach disorders; (I), dec.

$0.01 \quad 0.01$

Petroselinum crispum (Mill.) Fuss*

Maydanoz

A.p.

For inflammation; (I), e.d.

$0.01 \quad 0.01$

Araceae

For hemorrhoid; (I), mixed with rye flour and honey to obtain a pill and eaten on empty

Arum euxinum R. R. Mill (2631, 2645)

5, 12 Gavur

Ro.

mancarı stomach for a few days. Or smashed Ro. are mixed with honey and eaten.

For leukemia; (I), e.d. or cooked.

For hypercholesterolemia; (I), e.d.

As foodstuff; (I), e.d. (just L.) or roasted, mixed

Ro./ L. with honey and eaten.

\begin{tabular}{lllllll}
\hline Berberidaceae & & & & \\
\hline Berberis crataegina DC. (2732) & 46 & Ak çalı & Fr. & For pain; (I), dec. & 0.01 & 0.01 \\
\hline Betulaceae & & & & & & \\
\hline Corylus avellana L. & - & Fındık & L. & $\begin{array}{l}\text { For snake bite; (E), crushed leaves are } \\
\text { wrapped on affected area. }\end{array}$ & 0.01 & 0.01
\end{tabular}

Boraginaceae

For wound healing and abscess; (E), Ro. is roasted with butter to obtain an ointment, then app. aff. and covered with cloth. Or Ro.

Echium italicum L. (2653)

Kızılcık otu, kızılbacak
Ro. collected in the autumn are chopped, mixed with soap, sugar and egg yolk (this mixture is named as "sweet ointment"), app. aff., covered with cloth.

\begin{tabular}{|c|c|c|c|c|c|c|}
\hline \multicolumn{7}{|l|}{ Brassicaceae } \\
\hline Sinapis arvensis L. (2728) & 46 & Hardal & Se. & For kidney stone; (I), eaten. & 0.01 & 0.01 \\
\hline \multicolumn{7}{|l|}{ Colchicaceae } \\
\hline $\begin{array}{l}\text { Colchicum szovitsii Fisch. \& C. A. } \\
\text { Mey. (2644) }\end{array}$ & 12 & $\begin{array}{l}\text { Siğilotu, boru } \\
\text { otu }\end{array}$ & $\mathrm{L}$. & For hyperglycemia; (I), as dec. & 0.01 & 0.01 \\
\hline \multicolumn{7}{|l|}{ Compositae } \\
\hline Achillea sp. (2627) & 3 & Kokağan otu & A.p. & As perfume; (E), applied to hands. & 0.01 & 0.01 \\
\hline $\begin{array}{l}\text { Arctium minus (Hill) Bernh. (2651, } \\
2704,2717 \text { ) }\end{array}$ & $16,42,46$ & Kabalak & L. & $\begin{array}{l}\text { For rheumatismal pain; (E), wrapped on } \\
\text { affected area until recovery with intervals. }\end{array}$ & 0.05 & 0.05 \\
\hline $\begin{array}{l}\text { Cota tinctoria (L.) J. Gay (2666, } \\
2680,2694,2698,2711)\end{array}$ & $\begin{array}{l}32,36 \\
27,38,45\end{array}$ & $\begin{array}{l}\text { Beyaz } \\
\text { papatya, } \\
\text { papatya, } \\
\text { akbaba }\end{array}$ & F. & $\begin{array}{l}\text { For stomach disorders; (I), dec. with Rosa } \\
\text { canina L. Fr. (daily } 3 \times 1-2 \text { tea glass full dec. for } \\
1-2 \text { month). } \\
\text { For cough and stomachache; (I), dec. with } \\
\text { apple Fr. rind. } \\
\text { For urinary tract inflammation; (I), inf. is drunk } \\
\text { until recovery. } \\
\text { To lose weight, as diuretic; (I), dec. }\end{array}$ & 0.10 & 0.35 \\
\hline
\end{tabular}


Table 1. continued

Family and scientific name (GUEF no)

Centaurea solstitialis L. (2656)

Chondrilla juncea L. (2686)

Cichorium intybus L. (2731, 2750)

Cirsium arvense (L.) Scop. (2709)

Cyanus depressus (M. Bieb.) Soják
(2707)

\begin{tabular}{lclll}
\hline Inula oculus-christi L. (2743) & 50 & Mayasılotu & L. \\
\hline Onopordum turcicum Danin (2695) & 27 & Galgan & F. \\
\hline $\begin{array}{l}\text { Taraxacum scaturiginosum G. E. } \\
\text { Haglund (2633) }\end{array}$ & 6 & $\begin{array}{l}\text { Ağacakavağı, } \\
\text { hindiba, eşek } \\
\text { karakavuğu }\end{array}$ & L. \\
\hline Tragopogon dubius Scop. (2730) & 46 & Yemlik & L. \\
\hline
\end{tabular}

\begin{abstract}
Tripleurospermum elongatum (DC.) Bornm. (2641, 2714)
\end{abstract}

11, $46 \quad$ Papatya otu L.
A.p.
Purpose of usage, preparation and application method $^{b}$

UV $\quad \mathrm{Cl}$

For hemorrhoid and constipation; (I), a glass of dec. is drunk on empty stomach.

$0.03 \quad 0.01$

As stomachic; (I), Lt. obtained from Ro. is air dried and chewed.

$0.01 \quad 0.01$

For dental disorders; (I), Lt. obtained from drilled Ro. is dried and chewed.

$0.03 \quad 0.03$

For urinary tract and prostate disorders; (I), as dec.

$0.03 \quad 0.01$

For heart health and vascular occlusion; (I), $\begin{array}{lll}\text { dec. is prepared with a sprinkle of A.p. and } & 0.03 & 0.01\end{array}$ drunk after gets warm.

For hemorrhoid; (I), dried and crushed leaves are drunk with a glass of water.

$0.01 \quad 0.01$

$\begin{array}{lll}\text { For hyperglycemia; (I), dec. } & 0.01 & 0.01\end{array}$

For hyperglycemia, hypertension and hypercholesterolemia; (I), e.d.

$0.05 \quad 0.03$

For wound healing; (I), e.d.

$0.01 \quad 0.01$

For bronchitis; (I), inf. (daily 1 glass on empty stomach in the mornings or 3-4x1 glass) or inf. with A.p. of Urtica dioica $L$.

For stomach disorders; (I), dec.

$0.05 \quad 0.10$

For prostate disorders; (I), inf. with A.p. of

Urtica dioica L.

\section{Cucurbitaceae}

Citrullus lanatus (Thunb.) Matsum.

\& Nakai*

Karpuz Fr.

For stomachache and prostate disorders; (I), Fr. juice is drunk (daily $2 \times 1$ glass) on empty stomach for at least one week.

Cupressaceae

Juniperus communis L. var. saxatilis Pall. (2652, 2712)

16, 46 Ardıç

Ro., S.

For eczema; (I), tar obtained from Ro. and S. by dry distillation is drunk with water on empty stomach.

$0.03 \quad 0.07$

Fr. For shortness of breath; (I), as dec.

\section{Euphorbiaceae}

Euphorbia condylocarpa M. Bieb. (2648)

12 Sütleğen Lt.

Lt.

For inflamed wounds; Lt. that obtained from torn plant were app. aff.

$0.01 \quad 0.01$

\section{Fagaceae}

\begin{tabular}{|c|c|c|c|c|c|c|}
\hline & & & G. & For heart disorders; (I), e.d. & & \\
\hline Quercus robur L. $(2653,2721)$ & 21,46 & $\begin{array}{l}\text { Meşe, } \\
\text { karaağaç }\end{array}$ & $\begin{array}{l}\text { L. } \\
\text { Ro. }\end{array}$ & $\begin{array}{l}\text { For stomachache; (I), dec. } \\
\text { For knee pain; (E), prepared po. from fresh } \\
\text { Ro., app. aff. for one night. This application is } \\
\text { repeated for 3-4 day. }\end{array}$ & 0.05 & 0.10 \\
\hline \multicolumn{7}{|l|}{ Hypericaceae } \\
\hline $\begin{array}{l}\text { Hypericum heterophyllum Vent. } \\
\text { (2677) }\end{array}$ & 33 & Yağșan otu & A.p. & For wounds on animals: (E), app. aff. & 0.01 & 0.01 \\
\hline
\end{tabular}


Table 1. continued

Family and scientific name (GUEF no)
Locality $^{\mathrm{a}} \quad$ Local name Used part ${ }^{\mathrm{b}}$

Purpose of usage, preparation and application method $^{\mathrm{b}}$

For stomachache or gastric ulcer; (I), as dec. is drunk until the pain is over.
A.p., F.
UV $\quad \mathrm{Cl}$

Hypericum perforatum L. (2663,

$0.05 \quad 0.05$ 2670, 2691)

$32,33,27-$

Juglandaceae
For diabetes; (I), 15-20 Se. crushed and macerated in a glass of water for one night. In the morning, a tea cup of maceration water is drunk and 1-2 Se. are eaten. Or juice of half lemon and 3 Se. are added to a glass of water and waited for one night. In the morning, maceration water is drunk and Se. is eaten. This application is repeated for 15-20 days. For, high cholesterol; (I), fresh cotyledons macerated with water for one night. In the morning, maceration water is drunk and cotyledons are eaten.

For goiter; (I), marble sized immature Se. is swallowed with water.

Lamiaceae

Ajuga chamaepitys (L.) Schreb. subsp. chia (Schreb.) Arcang.

12 Ömür çiçeği F.

For hemorrhoid; (E), directly app. aff.

Juglans regia L. (2652, 2697, 2705,

$19,38,42$,

Se. (2647)

Ballota larendana Boiss. \& Heldr. (2724)
A.p.
For women's infertility; (E), boiled with milk and used as sitz bath for one week. Application starts in the morning and continues until the evening. It causes excessive sweating. At this time, patient should be protected from cold.

\begin{tabular}{|c|c|c|c|c|c|c|}
\hline Mentha aquatica L. $(2628,2748)$ & 3,51 & Su nanesi & $\mathrm{L}$. & For stomachache; (I), dec. & 0.03 & 0.03 \\
\hline Mentha longifolia (L.) L. (2667) & 32 & Yarpuz & A.p. & For inflammation; (I), inf. & 0.01 & 0.01 \\
\hline Mentha $\times$ piperita L. ${ }^{*}(2737)$ & 46 & Nane & A.p. & $\begin{array}{l}\text { For abdominal pain and common cold; (I), e.d. } \\
\text { or as dec. }\end{array}$ & 0.07 & 0.03 \\
\hline Phlomis sp. (2640) & 11 & Kedi kulağı & A.p. & For gastric ulcer; (I), inf. (daily 2-3x1 glass). & 0.01 & 0.01 \\
\hline
\end{tabular}

Sideritis germanicopolitana Bornm. (2672)

33 Adaçayı A.p.

For cough; (I), inf. with lemon and thyme.

For kidney inflammation and other inflammations; (I), inf. with one slice of lemon $\quad 0.05 \quad 0.05$ (people who have liver diseases should not use this preparation).

For stomachache, asthma, bronchitis and as panacea; (I), inf.

$0.08 \quad 0.21$ For cough; (I), inf. with F. of Cota tinctoria.

For cough; (I), inf. is prepared by a sprinkle of $\begin{array}{lll}\text { Thymus leucotrichus, A.p. of sage and lemon } & 0.01 & 0.01\end{array}$ for 5-10 minutes, drunk after adding sugar.

For asthma and bronchitis; (I), inf. (daily $3 \times 1-2$ tea cup, for 1-3 months).

For stomach disorders; (I), inf.

$0.07 \quad 0.08$
Thymus longicaulis C. Presl subsp. chaubardii (Rchb.f.) Jalas (2646, 2664)

12, $32 \quad$ Kekik A.p.


Table 1. continued

Family and scientific name (GUEF no)

Locality $^{\mathrm{a}} \quad$ Local name Used part ${ }^{\mathrm{b}}$

Purpose of usage, preparation and application method $^{b}$

Malva neglecta Wallr. $(2635,2665$

2682, 2689, 2723, 2747)
10, 32,

36,27 ,

46,51
Ebemgömeci, A.p. ebemkömeci
For hyperglycemia; (I), inf. or e.d. or cooked as meal.

For stomach disorders; (I), inf. or e.d. or cooked as meal. (E), po. m., applied on abdomen.

For constipation; (E), po. m., applied on abdomen. (I), e.d. or dec.

For hemorrhoid; (E), fresh or dried A.p. boiled with milk and app. aff. This application drains the inflammation. Or (I), cooked as meal.

For pain in waist and knee, rheumatismal pain;

(E), boiled to obtain a po. and app. aff. or (I), dec

Women's infertility; crushed and boiled in water and milk added to obtain a po., after the milk has absorbed, placed into uterus. Or boiled in milk, as sitz bath. Or crushed and boiled in milk and water to obtain a po., then placed into uterus. Or boiled in milk, as sitz bath.

For prostate disorders; (I), dec.

For common cold; (I), inf.

For asthma, cough, tonsillitis, abdominal pain and as sedative for children; (I), as dec. Residue could be used to prepare dec. for 2-3

times.
(Rupr.) V. Engl. (2675, 2678) ıhlamur, dağ

inlamuru with bracts

\section{Moraceae}

Morus nigra L. * (2735)

\section{Orobanchaceae}

Rhinanthus serotinus (Schönh.)

Oborny subsp. aestivalis

(N.W.Zinger) Dostál (2715)

\section{Papaveraceae}

Chelidonium majus L. (2685)

36

Temreotu

Lt.

For "temre" (a skin disorder); (E), the Lt. that running from plucked leaves is app. aff.

For shortness of breath and asthma; (I), inf. is drunk at two times a day after waiting in cold for one night. Or e.d.

For shortness of breath and asthma; (I), dec., S. for 10 days

For inflamed wounds; (I), dec.

Pinus nigra J. F. Arnold subsp. pallasiana (Lamb.) Holmboe (2639)
11

Çam
For shortness of breath and asthma; (I), mixed with honey.

For abscess and wound healing; (E), directly, or mixed with honey or mixed with soap, app. aff. It heals the wound and drains the inflammation.

For removing foreign objects from skin (e.g. splinter); (E), app. aff. 
Table 1. continued

Family and scientific name (GUEF no)

Locality $^{\mathrm{a}} \quad$ Local name Used part ${ }^{\mathrm{b}}$

$\mathrm{Ph} \quad$ For lung disorders, tuberculosis, asthma, stomachache; (I), mixed with honey and eaten.

Stomach disorders; (I), crushed, mixed with honey and eaten.

Se.

For shortness of breath; (I), crushed Se. is mixed with honey and eaten.

Pinus sylvestris L. (2625, 2638, 2654, 2746)
For removing foreign objects from skin (e.g. splinter); (E), app. aff.

For shortness of breath: (I), dec. prepared with a handful of $C$. that collected in the November. Or small immature $C$. is mixed with honey and eaten.

Women's urinary tract disorders; (I), dec. with C., equal amount of leaves of Cydonia oblonga and A.p. of nettle ( 3 times in a day, for 1-3 months).

\section{Plantaginaceae}

Plantago major L. $(2703,2706,2710$, 2716)

42, 45, 46 Siğil otu L.

For abscess; (E), app. aff.

For gastric ulcer; (I), mixed with honey, butter $\quad 0.05 \quad 0.10$ and eaten.

\section{Polygonaceae}

Polygonum cognatum Meissn. (2629, 2634, 2688)

Madımalak, kadımalak, dağ mancarı,

A.p. üfelek

Rumex crispus L. $(2649,2749)$

Kenger kuzukulağı

L.

Rumex scutatus L. (2626)
Rumex sp. (2739)

Portulacaceae

\begin{tabular}{|c|c|c|c|c|c|c|}
\hline Portulaca oleracea L. (2733) & 46 & $\begin{array}{l}\text { Sirkenotu, } \\
\text { semizotu }\end{array}$ & A.p. & $\begin{array}{l}\text { For hyperglycemia, inappetency and cancer; } \\
\text { (I), e.d. }\end{array}$ & 0.05 & 0.01 \\
\hline \multicolumn{7}{|l|}{ Ranunculaceae } \\
\hline Nigella sativa L.* & - & Çörekotu & Se. & For shortness of breath; (I), mixed with honey. & 0.01 & 0.01 \\
\hline \multicolumn{7}{|l|}{ Rhamnaceae } \\
\hline $\begin{array}{l}\text { Paliurus spina-christi Mill. (2708, } \\
\text { 2751) }\end{array}$ & 42,51 & Karaçalı & Fr. & $\begin{array}{l}\text { For stomach disorders and kidney stone; (I), } \\
\text { dec. }\end{array}$ & 0.03 & 0.07 \\
\hline \multicolumn{7}{|l|}{ Rosaceae } \\
\hline $\begin{array}{l}\text { Crataegus orientalis Pall. ex M. Bieb. } \\
(2740)\end{array}$ & 46 & Kürdili & $\begin{array}{l}\text { Fr. } \\
\text { F. }\end{array}$ & $\begin{array}{l}\text { For diarrhea and stomach disorders; (I), } \\
\text { mature Fr. are eaten. } \\
\text { For hypertension and hyperglycemia; (I), inf. is } \\
\text { drunk in the mornings on empty stomach. }\end{array}$ & 0.07 & 0.05 \\
\hline Cydonia oblonga Mill. $(2660,2692)$ & 28,27 & Ayva & $\mathrm{L}$. & $\begin{array}{l}\text { For shortness of breath, bronchitis and cough; } \\
\text { (I), dec. is drunk with lemon juice. } \\
\text { For women's urinary tract disorders; (I), as } \\
\text { dec. with equal amount of leaves of Cydonia } \\
\text { oblonga, C. of Pinus sylvestris L. and A.p. of } \\
\text { Urtica dioica L. (daily } 3 \times 1 \text {, for } 1-3 \text { month). }\end{array}$ & 0.07 & 0.03 \\
\hline
\end{tabular}

For stomach and intestinal disorders; (I), boiled and eaten.

$0.05 \quad 0.10$ As foodstuff: (I), e.d.

For hyperglycemia; (I), e.d. As appetite suppressant; (I), eaten. As foodstuff; (I), e.d. $0.01 \quad 0.01$

3 Acıkıcı A.p.

For hyperglycemia; (I), e.d.

$0.01 \quad 0.01$

L.

For hyperglycemia; (I), e.d. 
Table 1. continued

Family and scientific name (GUEF no)

Locality ${ }^{\mathrm{a}} \quad$ Local name Used part ${ }^{\mathrm{b}}$

Purpose of usage, preparation and application method $^{\mathrm{b}}$

For hyperglycemia; (I), sugar free compote is prepared with dried Fr. and drunk. Or dried

Malus sylvestris (L.) Mill. (2683)

36

Acr elma, yabani elma

Fr. layers of Fr. pulp (this preparation is called as "pestil") are eaten. Or pestil is macerated in water and drunk.

For hyperglycemia; (I), sugar free compote that $\begin{array}{lll}\text { prepared from Fr. is drunk, marc is eaten as } & 0.01 & 0.01\end{array}$ well.

Prunus cerasus L. ${ }^{\star}(2734$

46

Vişne

Fr.

Prunus spinosa L. $(2636,2713,2725)$

10,46

Karamuk

Fr.

r.

Rosa canina L. (2632, 2662, 2673, 2687,2718 )

6, 32, 33, Kuşburnu Fr.
36,46

\begin{tabular}{|c|c|}
\hline For hyperglycemia; (I), dec. prepared from & 0.03 \\
\hline
\end{tabular}

For bronchitis; (I), dec. Or Fr. juice is drunk. Or jam prepared from $\mathrm{Fr}$. is consumed twice a day.

For cough and shortness of breath; (I), inf. For hemorrhoid; (I), dec. prepared by boiling for 15 minutes is drunk after get warm. For hyperglycemia; (I), Fr. juice is boiled and drunk on empty stomach (daily $2 \times 1$ tea cup). For hypertension; (I), viscous dec. is mixed with water, drunk in the evenings (daily $2-3$ glass).

For stomach disorders; (I), dec. of Fr. with F. of Cota tinctoria (daily $3 \times 1-2$ tea cup, for $1-2$ month).

For prevent diseases; (I), mature Fr. are boiled for 1-2 hour, squashed, sieved, remaining pulps is drunk with water or eaten.

For wound healing; (E), crushed, mixed with butter, app. aff.

For lung disorders; (I), mixed with honey and $0.03 \quad 0.03$ eaten.

Fr. For children's diarrhea; (I), e.d.

Sorbus domestica L. $(2736,2742$, 2744)

46, 50, 51 Övez

Fr. and L.

For urinary tract disorders; (I), dec.

For kidney stone; (I), prepared inf. is drunk on

0.05

L. empty stomach after waiting in cold for one night.

Sorbus umbellata (Desf.) Fritsch (2741)

46

Alıç

Fr.

For hyperglycemia and heart disorders; (I), dec.

$\mathrm{Cl}$ 
Table 1. continued

Family and scientific name (GUEF no)

Viscum album L. subsp. austriacum (Wiesb.) Vollm. (2727)

Scrophulariaceae

Verbascum insulare Boiss. \&Heldr. (2643, 2684, 2701, 2722)
F.

12, 36, 42 Sığırkuyruğu

\section{A.p.}

Purpose of usage, preparation and application method $^{b}$

UV $\quad \mathrm{CI}$

For urinary tract inflammation, bronchitis and

$0.05 \quad 0.03$ cough; (I), dec.

Fr.

raction,

For wounds on animals: (E), crushed and app. aff.

For wounds on animals: (E), wrapped on wounds, this application kills worms on 0.05 0.15 wounds.

For fishing: immersed to water. This application kills the fishes.
Urtica dioica L. $(2655,2658,2661$, $2671,2679,2696,2738,2745$ )
For women's urinary tract disorders; (I), dec. with equal amount of A.p. of Urtica dioica, C. of Pinus sylvestris and leaves of Cydonia oblonga is drunk 3 times a day for 1-3 months. For prostate disorders; (I), inf., on empty stomach, in the evenings.

For prostate cancer; (I), inf. is prepared with $500 \mathrm{~g}$ fresh A.p. and $4 \mathrm{~L}$ water, drunk on empty stomach.

For prostate disorders and bronchitis; (I), inf. with leaves of Tripleurospermum elongatum.

A.p. $\quad$ For rheumatism; (I), 1-2 glass of dec. was drunk every day.

For shortness of breath; (I), A.p. (without F. and Se.) cooked as meal and eaten every day.
25,27 ,

32,33 ,

36,38 ,

46, 51
Dalağan otu, Isırgan otu For dandruff; (E), dec. of fresh A.p. is applied on scalp after shower. After waiting a while, hair is rinsed. This application is repeated three consecutive baths.

For hemorrhoid; (I), inf. is drunk three times a day on empty stomach. Residue could be used to prepare inf. once more.

As foodstuff: cooked as meal.

For urinary tract disorders, lung and urinary

A.p. with Se. tract cancer; (I), a glass of dec. is drunk 3 times a day on empty stomach.

Se. For cancer; (I), as dec./inf. or consumed with honey or eaten with meals.

For knee pain or rheumatism; (E), knee was bitten to green thin hornet, and L. of Urtica dioica app. aff. Or fresh L. is wrapped on affected are for 5-10 minutes.

a: Localities that corresponds the numbers are given in Figure 1, b: Abbreviations, *: Cultivated plants, A.p.: Aerial parts, app. aff.: Applied on affected area, C.: Cone, dec.: Decoction, E: Externally, e.d.: Eaten directly, F.: Flower, Fr.: Fruit, G.: Gall, I: Internally, inf.: Infusion, L.: Leaf, Lt.: Latex, Ph.: Phloem, po.: Poultice, po. m.: Poultice with milk, R.: Resin, Ro.: Root, S.: Stem, Se.: Seed, W.p.: Whole plant, UV: Use value, Cl: Cultural importance index 
During the field studies, diseases that local people tried to treat with folk remedies were classified into 11 groups (Table 3 ). The distribution of folk medicines according to pharmacological categories in Kızılcahamam is as follows: Respiratory system disorders, 18 medicines and 47 citations; gastrointestinal problems, 28 medicines and 44 citations, and urinary tract problems, 17 medicines and 29 citations (Table 3). Shortness of breath is the most referenced respiratory system disorder that is treated by folk medicines, while hemorrhoid and prostate disorders are illnesses that are attempted to be cured by folk medicines among gastrointestinal system and urinary tract problems. However, this order changes when FIC values are considered; dental diseases have the highest FIC value (1.00), followed by skeletomuscular system disorders (0.69) and respiratory system disorders (0.63) that ranked second and third, respectively. FIC is accepted as being the degree of agreement among the people interviewed concerning the use of a given taxon. ${ }^{14}$ Thus, differences according to citation and FIC value were thought to be based on the disagreement among informants and the use of the same folk medicine for very different purposes. Dental disorders have the highest FIC value because of the citation of the same plant twice for dental illness, rather than being popular.

During our field study, a mushroom (Morchella sp.) was used for ethnobotanical purposes. It was named as "Kuzugöbeği, ayı mantarı" among local people and used for knee pain, inducing sleep, sedation, and foodstuff by cooking as meal. As it is a member of Kingdom Fungi, it was not listed in the table with other plant-sourced medicines.

\section{DISCUSSION}

The result of field studies conducted in the Kızılcahamam district provided important contributions to Turkish Folk Medicine literature. To the best of our knowledge, folk medicinal usage of Beta lomatogona, Ballota larendana, Tripleurospermum elongatum, and Verbascum insulare are recorded firstly within this research in Turkey (Table 1). In addition, four endemic plants, namely, Arum euxinum, Ballota larendana, Sideritis germanicopolitana, and Verbascum insulare, were used as folk remedies in the district.

Table 2. Distribution of folk medicines according to their preparation and application methods in Kızılcahamam

\begin{tabular}{|c|c|c|c|}
\hline Application method & Preparation method & Number & Percentages (\%) \\
\hline \multirow{2}{*}{ Externally } & a) Without processing, directly & 14 & 8.0 \\
\hline & b) After process (as poultice, ointment, ...) & 15 & 8.6 \\
\hline \multirow{4}{*}{ Internally } & a) Without processing, directly & 42 & 24.1 \\
\hline & b) Infusion & 29 & 16.7 \\
\hline & d) Decoction & 59 & 33.9 \\
\hline & e) Other preparations (as jam, pill, ...) & 6 & 3.5 \\
\hline Total & & 174 & 100.0 \\
\hline
\end{tabular}

Table 3. Distribution of used plants by pharmacological categories and FIC values

\begin{tabular}{|c|c|c|c|c|c|}
\hline Category of illness & Taxa & All taxa (\%) & Use citation & All use citation (\%) & FIC value \\
\hline Respiratory system disorders & 18 & 26.08 & 47 & 22.82 & 0.63 \\
\hline Gastrointestinal system disorders & 28 & 40.57 & 44 & 21.36 & 0.37 \\
\hline Urogenital system disorders & 17 & 24.63 & 29 & 14.08 & 0.43 \\
\hline Metabolic disorders & 16 & 23.18 & 25 & 12.14 & 0.38 \\
\hline Cardiovascular disorders & 9 & 13.04 & 11 & 5.34 & 0.20 \\
\hline Immunological disorders & 8 & 11.59 & 9 & 4.37 & 0.13 \\
\hline Central nervous system disorders & 3 & 4.34 & 3 & 1.45 & 0.00 \\
\hline
\end{tabular}

FIC: Informant consensus factor 
Folk medicines used in Kızılcahamam have similar usages in different parts of Turkey. The similarity is quite high with Çamlıdere, a border neighboring district of Kızılcahamam. Moreover, 27 of the 69 taxa used as folk medicines in Kızılcahamam have similar uses in Çamlıdere. For example, Cota tinctoria (urinary tract inflammation), Juglans regia (diabetes), Viscum album (shortness of breath and urinary tract disorders), Malva neglecta (hemorrhoid and rheumatism), Cydonia oblonga (shortness of breath, bronchitis, and cough), Prunus spinosa (diabetes) are used for same conditions in both districts. The utilization of Salix alba is an interesting example of this similarity, as the ash obtained from its root or leaf is applied to the head for the treatment of headache. ${ }^{2}$ In Güdül, another border neighboring district of Ankara, Paliurus spina-christi was used for kidney stone similar to its use in Kızılcahamam. ${ }^{7}$ Similar utilizations were also discovered with other remote districts of Ankara. For example, Malva neglecta, one of the most cited plants in our study area, is used for the treatment of hemorrhoids in Haymana and Beypazarı districts as in Kızılcahamam. 5,6 Taraxacum scaturiginosum was used for diabetes (or hyperglycemia) in both Beypazarı and Kızılcahamam districts. ${ }^{5}$ Echium italicum, Thymus leucostomus, and Sorbus domestica were used with the same purposes in different districts of Ankara. ${ }^{5}$ Similarities were observed with different provinces as well; for example, Crataegus orientalis is utilized for hypertension or hyperglycemia in different parts of Anatolia (e.g., Ağrı, Manisa) as in Kızılcahamam. ${ }^{17-19}$ Plantago major is used for the treatment of abscess in almost every part of Turkey as in Kızılcahamam.4-6,17,19-23 Furthermore, Ajuga chamaepitys subsp. chia, Morus nigra, Centaurea solstitialis, Echium italicum, and Sanguisorba minor were used in different provinces similarly as determined in our study area.,19,20,2326 Similar usages in nearby districts/provinces are already expected. Having similar flora and the ease of idea exchange could be the reasons for this situation. The similar use of folk medicines at different locations may be considered an indication of the accuracy of the identified folk medicinal knowledge. Besides, domestic migration, development of communication, and transport facilities may contribute to the dissemination of information to remote areas.

Conversely, different species of some genera used in Kızılcahamam were detected to have similar usages in different parts of Turkey. When the border neighboring districts were examined, interesting similar utilizations were encountered; one of them is Tripleurospermum callosum (Boiss. \& Heldr.) E. Hossain used for bronchitis in Çamlıdere, similar to Tripleurospermum elongatum. Similarities in the usage between Prunus avium (L.) L. and Prunus cerasus (diabetes and hyperglycemia), and between Juniperus oxycedrus L. and Juniperus communis var. saxatilis (for eczema) are among other examples. ${ }^{2}$ Similarly, in Güdül, Rumex tuberosus L. is used for hyperglycemia just as Rumex crispus is used in Kızılcahamam. ${ }^{7}$ Similar usages were also observed in remote districts of Ankara, such as between Onopordum turcicum and Onopordum acanthium L., and between Salix alba and Salix babylonica, which were used in Haymana. ${ }^{6}$ The same situation applies for other provinces of Turkey: Some different Hypericum species (e.g., Hypericum polyphyllum Boiss. \& Balansa and Hypericum empetrifolium Willd.) are utilized for the treatment of stomach disorders in Ağrı and Muğla, as in Kızılcahamam.17,27 Arum species are other examples. The root of Arum euxinum is used for hemorrhoid treatment in Kızılcahamam, and different Arum species (e.g., Arum balansanum R. R. Mill. and Arum italicum Mill.) are also used for the same purpose in different regions of Anatolia., 4,28,29 This may result from local people's assumption that different species of a genus are the same because of morphological similarities. Moreover, different species of a genus are likely to show phytochemical similarity. Thus, based on the information obtained from different regions by information exchange, people may have tried to prepare the same medicine with morphologically similar plants that are grown nearby, seen the same effect, and continued to use them.

Contrary to the abovementioned similarities, quite different usages for the same species were also determined in different parts of Ankara. These differences were observed even in border neighboring districts; for instance, Cirsium arvense is used for urinary tract and prostate disorders in Kızılcahamam, while it is used for shortness of breath in Çamlıdere. Sinapis arvensis is used for kidney stones in our research area, but it is recommended for shortness of breath in Çamlıdere. ${ }^{2}$ Another example is Crataegus orientalis, which is used for diarrhea, stomach disorders, hypertension, and hyperglycemia. Unlike the usages detected in Kızılcahamam, this plant is used for shortness of breath and heart disorders in the Güdül district. ${ }^{7}$ Arctium minus, Cichorium intybus, and Sinapis arvensis are other examples, which were used for different purposes in different districts of Ankara. ${ }^{8}$

The Anatolian Peninsula has hosted quite different cultures throughout history, and this situation has been inevitably reflected in folk medicinal knowledge. Communities, migrating from different regions throughout history, have blended their folk medicinal knowledge, which was obtained in the region where they came from, with local folk medicine knowledge. Therefore, the usage of the same plant as a folk remedy may vary by region.

Folk medicines are mostly cited for the treatment of gastrointestinal system disorders (especially hemorrhoid and stomach ache), respiratory (especially shortness of breath, asthma, and common colds), and urogenital system problems (especially, prostate disorders) in Kızılcahamam. Considering these results, the aforementioned disorders could be considered the most common health problems in the study area.

When the cited folk medicines are examined, some plants attract attention with their usage in the treatment of disorders which could be hardly noticed by common people. For example, Cirsium arvense, Citrullus lanatus, Malva neglecta, Tripleurospermum elongatum, Urtica dioica, and Viscum album are used for the treatment of prostate disorders, but the recognition of this disorder and use of folk medicine for its treatment are interesting. Likewise, informants expressed that they use various folk medicines to treat some illnesses, such 
as cancer (Arum euxinum, Urtica dioica, and Portulaca oleracea), hypercholesterolemia (Juglans regia), hyperglycemia (Prunus spinosa, Rosa canina, and Juglans regia), goiter (Juglans regia), and vascular occlusion (Cyanus depressus). Recently, these disorders are becoming increasingly widespread. In addition, at present, reaching a physician has become quite easy. Hence, these situations suggest that people start to search for solutions by themselves after being diagnosed by physicians. Moreover, this information could be obtained from various sources. Nevertheless, interviewees indicated that they learned these uses from their ancestors. Therefore, the mentioned usages were included in the present work. In addition, there may be some uses that may result from information pollution obtained from books, television, newspaper, etc., such as the use of Citrullus lanatus against prostate disorders. It is rich in lycopene ${ }^{30}$ that reduces the risk of prostate disorders. ${ }^{31}$ Methanol extract of seeds were demonstrated to cause a significant reduction in the size of the enlarged prostate..$^{32}$ However, this usage could be interpreted as a result of information pollution of folk medicine knowledge.

Some interesting folk remedies were encountered in the study area. For example, the phloem of Pinus sylvestris is consumed with honey as treatment of stomachache, or the knee is bitten by green thin hornets for the treatment of knee pain and rheumatism. Echium italicum is used for wound healing in Kızılcahamam, and according to previous bioactivity research, the ethanol extract of Echium italicum root increased wound tensile strength by $37 \%{ }^{33}$ Similarly. Hypericum perforatum, Phlomis sp., Malva neglecta, and Rosa canina are used as folk medicines in peptic ulcer symptoms, and in the literature, these plants have a strong in vivo anti-ulcerogenic effect. ${ }^{34-36}$ In addition, Pinus nigra subsp. pallasiana and Pinus sylvestris are interestingly used for removing foreign objects from the skin. When their resins were applied to the affected area, foreign materials such as splinters could be removed. The usage of Cota tinctoria for weight loss is also interesting. To the best of our knowledge, no study has examined this effect. The investigation of the mentioned effect of Cota tinctoria can be a new research topic. It is possible to increase the number of these examples. This situation is a good example to unroll the possible high potential of folk medicines as the starting point for new drug discovery.

Conversely, Onopordum turcicum flower is used against hyperglycemia in the research area. In our previous study, this plant species was used to treat diabetes in Çamlıdere, a neighboring district, and local names of this plant are very similar in both districts (called as "galgan" in Kızılcahamam and "Kalkan" in Çamlıdere). ${ }^{2}$ The usage of the same folk medicines for the same purposes in two neighboring regions increases the reliability of the data obtained in this study.

In Kızılcahamam, folk medicines are generally preferred if prepared from a single plant species; only 17 of 69 taxa are included in the mixtures. These mixtures are usually prepared as decoction/infusion (e.g., Cota tinctoria, Cydonia oblonga, and Rosa canina), but there are some ointment (e.g., Echium italicum) or poultice (e.g., Malva neglecta) formulations, as well. These results are consistent with the folk medicine data previously obtained in Turkey because folk remedies are generally prepared as simple formulations and used as a single component.

In this study, although investigations aimed at folk remedies, other ethnobotanical usages of plants rather than their usage in folk medicine were also detected and recorded on the field. For example, Achillea sp. is used as perfume by applied on hands; Arum euxinum, Morchella sp., Polygonum cognatum, Rumex scutatus, Thymus longicaulis subsp. chaubardii, and Urtica dioica are used as foodstuff, and Verbascum insulare is used for fishing.

As a result of interviews, the majority of informants in the research area preferred to use modern medicine for the treatment of their illnesses; by contrast, some of the informants expressed that they do not want to use modern medicines because of their side effects, so they try treating illnesses with herbal remedies. However, people who know about folk medicines are limited; in 51 villages, no knowledgeable people or folk medicine users were found in 21 villages ( $41 \%$ of visited locations). However, if this survey was conducted 20 years ago, ethnobotanical information could probably be obtained from all villages. This situation is a very important indicator of the loss of ethnobotanical knowledge owing to modern life.

\section{CONCLUSION}

To the best of our knowledge, this is the first study to explore folk medicines in the Kızılcahamam district. This study provided important contributions to the inventory of Turkish Folk Medicines. This study also highlights the rapid disappearance of folk medicine knowledge and urgent need for recording it in all parts of Turkey. Folk remedies are important resources, as they provide advantages on modern drug research. They could be considered as sources that have been shown to be effective on humans and tested for toxicity because they have been used for centuries, and useless or toxic ones were discarded throughout history. In previous bioactivity studies based on folk medicines conducted by our research group, many herbs used as folk remedies in different regions of Anatolia have been shown to be effective against the mentioned bioactivities in vivo. $34,35,37-$ ${ }^{40}$ Many drugs have been developed based on their traditional use worldwide; aspirin (Salix sp.), artemisinin (Artemisia annua L.), galantamine (Galanthus woronowii Losinsk.) are some examples of compounds developed from plants that were used traditionally. $41-43$ Besides recording new folk medicines to the ethnobotanical heritage of Turkey, this study is a valuable source of data for future bioactivity studies and discovery of new drug candidate molecules.

Conflict of interest: No conflict of interest was declared by the authors. The authors alone are responsible for the content and writing of the paper.

\section{REFERENCES}

1. Guner A, Ozhatay N, Ekim T, Baser K. Flora of Turkey and the East Aegean Islands Edinburgh; Edinburgh University Press; 2000. 
2. Günbatan T, Gürbüz I, Özkan AMG. The current status of ethnopharmacobotanical knowledge in Çamlıdere (Ankara, Turkey). Turk J Bot. 2016;40:241-249.

3. Karcı E, Gürbüz İ, Akaydın G, Günbatan T. Folk medicines of Bafra (Samsun-Turkey). Turk J Biochem. 2017;42:381-399.

4. Gürbüz I, Gençler-Özkan AM, Akaydın G, Salihoğlu E, Günbatan T, Demirci F, Yeşilada E. Folk medicine in Düzce province (Turkey). Turk J Bot. 2019;43:769-784.

5. Şimşek I, Aytekin F, Yeșilada E, Yıldırımlı Ș. An ethnobotanical survey of the Beypazarı, Ayaş, and Güdül district towns of Ankara province (Turkey). Econ Bot. 2004;58:705-720.

6. Sarper F, Akaydın G, Şimşek I, Yeșilada E. An ethnobotanical field survey in the Haymana district of Ankara province in Turkey. Turk J Biol. 2009;33:79-88.

7. Elçi B, Erik S. Güdül (Ankara) ve çevresinin etnobotanik özellikleri. Hacettepe Üniv Ecz Fak Der. 20006;26:57-64.

8. Sezik E, Yeșilada E, Honda G, Takaishi Y, Takeda Y, Tanaka T. Traditional medicine in Turkey X. folk medicine in central Anatolia. J Ethnopharmacol. 2001;75:95-115.

9. Eker M. Yabanabad 2000 (1 ed). Ankara; Kızılcahamam Belediyesi Yayınları; 2001.

10. Davis PH. Flora of Turkey and the East Aegean Islands (1 ed). Edinburgh, UK; Edinburgh University Press; 1965-1985.

11. Davis P, Mill R, Tan K. Flora of Turkey and the East Eagean Islands. Edinburgh; Edinburgh University Press; 1988.

12. Güner A, Aslan S, Ekim T, Vural M, Babaç MT. Türkiye Bitkileri Listesi (Damarlı Bitkiler). İstanbul; Nezahat Gökyiğit Botanik Bahçesi ve Flora Araştırmaları Derneği Yayını; 2012.

13. Abe R, Ohtani K. An ethnobotanical study of medicinal plants and traditional therapies on Batan Island, the Philippines. J Ethnopharmacol. 2013;145:554-565.

14. Albuquerque UP, Lucena RFP, Montero JM, Florentino ATN, Almeida CF. Evaluating two quantitative ethnobotanical techniques. Ethnobot Res App. 2006;4:51-60.

15. Trotter RT, Logan MH. Informant concensus, a new approach for identifying potentially effective medicinal plants. In: Etkin NL, ed. Plants in indigenous medicine and diet, biobehavioural approaches. New York, USA: Redgrave Publishing Company; 1986:91-112.

16. Tardío J, Pardo-De-Santayana M. Cultural importance indices: a comparative analysis based on the useful wild plants of Southern Cantabria (Northern Spain). Econ Bot. 2008;62:24-39.

17. Dalar A, Mukemre M, Unal M, Ozgokce F. Traditional medicinal plants of Agri Province, Turkey. J Ethnopharmacol. 2018;226:56-72.

18. Sargın SA, Akçiçek E, Selvi S. An ethnobotanical study of medicinal plants used by the local people of Alaşehir (Manisa) in Turkey. J Ethnopharmacol. 2013;150:860-874.

19. Sargın SA, Selvi S, Lopez V. Ethnomedicinal plants of Sarıgöl district (Manisa), Turkey. J Ethnopharmacol. 2015;171:64-84.

20. Özkan AMG, Koyuncu M. Traditional medicinal plants used in Pınarbaşı area (Kayseri-Turkey). Turk J Pharm Sci. 2005;2:63-83.

21. Mukemre M, Behcet L, Cakilcioglu U. Ethnobotanical study on medicinal plants in villages of Catak (Van-Turkey). J Ethnopharmacol. 2015;166:361374.
22. Polat R. Ethnobotanical study on medicinal plants in Bingöl (City center) (Turkey). J Herb Med. 2019;16:100211.

23. Yesilyurt EB, Simsek I, Akaydin G, Yesilada E. An ethnobotanical survey in selected districts of the Black Sea region (Turkey). Turk J Bot. 2017; $41: 47-62$.

24. Akaydın G, Şimşek I, Arıtuluk Z, Yeșilada E. An ethnobotanical survey in the selected towns of mediterranean subregion (Turkey). Turk J Biol. 2013;37:230-247.

25. Yeșilyurt EB, Şimşek I, Tuncel T, Akaydın G, Yeșilada E. Marmara Bölgesi'nin bazı yerleșim merkezlerinde halk ilacı olarak kullanılan bitkiler. Marmara Pharm J. 2017;21:132-148.

26. Han MI, Bulut G. The folk-medicinal plants of Kadişehri (Yozgat - Turkey). Acta Soc Bot. Pol. 2015;84:237-248.

27. Gürdal B, Kültür Ş. An ethnobotanical study of medicinal plants in Marmaris. J Ethnopharmacol. 2013;146:113-126.

28. Yeșilada E, Honda G, Sezik E, Tabata M, Fujita T, Tanaka T, Takeda Y, Takaishi Y. Traditional medicine in Turkey. V. folk medicine in the Inner Taurus Mountains. J Ethnopharmacol. 1995;46:133-152.

29. Honda G, Yeşilada E, Tabata M, Sezik E, Fujita T, Takeda Y, Takaishi Y, Tanaka T. Traditional medicine in Turkey VI. folk medicine in West Anatolia: Afyon, Kütahya, Denizli, Muğla, Aydın provinces. J Ethnopharmacol. 1996;53:75-87.

30. Oghenesurwe E, Emeka I, Lotanna A, Sonne M, Goodies M. Toxicity evaluation of a commercial herbal preparation commonly used in Nigeria. Eur J Med Plant. 2015;5:176-190.

31. Carini F, Zeenny MN, Mazzola M, Trapani BD, Palumbo V, Gerges AG, Sinagra E, Leone A, Tomasello G. Lycopene and prostate cancer: an overview. Prog Nutr. 2018;20:545-548.

32. Olamide AA, Olayemi OO, Demetrius OO, Olatoye OJ, Kehinde AA. Effects of Methanolic extract of Citrullus lanatus seed on experimentally induced prostatic hyperplasia. Eur J Med Plant. 2011;1:171-179.

33. Eruygur N, Yilmaz G, Kutsal O, Yucel G, Ustun O. Bioassay-guided isolation of wound healing active compounds from Echium species growing in Turkey. J Ethnopharmacol. 2016;185:370-376.

34. Gürbüz I, Üstün $O$, Yesilada E, Sezik E, Kutsal O. Anti-ulcerogenic activity of some plants used as folk remedy in Turkey. J Ethnopharmacol. 2003;88:93-97.

35. Gürbüz I, Özkan AMG, Yeșilada E, Kutsal O. Anti-ulcerogenic activity of some plants used in folk medicine of Pınarbașı (Kayseri, Turkey). J Ethnopharmacol. 2005;101:313-318.

36. Yeșilada E, Gürbüz I. Evaluation of the antiulcerogenic effect of the flowering herbs of Hypericum perforatum L. J Fac Pharm Gazı Univ. 1998;15:77-83.

37. Gürbüz I, Üstün O, Yeșilada E, Sezik E, Akyürek N. In vivo gastroprotective effects of five Turkish folk remedies against ethanol-induced lesions. J Ethnopharmacol. 2002;83:241-244.

38. Yesilada E, Gurbuz I, Toker G. Anti-ulcerogenic activity and isolation of the active principles from Sambucus ebulus L. leaves. J Ethnopharmacol. 2014;153:478-483.

39. Gurbuz I, Yesilada E, Baser KHC. Characterization of volatiles and antiulcerogenic effect of Turkish sweetgum balsam (Styrax liquidus). J Ethnopharmacol. 2013;148:332-336. 
40. Gunbatan T, Gurbuz I, Bedir E, Gencler Ozkan AM, Ozcinar O. Investigations on the anti-ulcerogenic activity of Sideritis caesarea $\mathrm{H}$. Duman, Aytac \& Baser. J Ethnopharmacol. 2020;258:112920.

41. Gertsch J. How scientific is the science in ethnopharmacology? Historical perspectives and epistemological problems. J Ethnopharmacol. 2009;122:177-183.
42. Agtmael MA, Eggelte TA, Boxte CJ. Artemisinin drugs in the treatment of malaria: from medicinal herb to registered medication. Trends Pharm Sci. 1999;20:199-205.

43. Heinrich M, Teoh HL. Galanthamine from snowdrop-the development of a modern drug against Alzheimer's disease from local Caucasian knowledge. J Ethnopharmacol. 2004;92:147-162. 